\title{
電子診療録へのスタンプ貼付によるベンゾジアゼピン受容体作動薬減薬の取り組みとその評価
}

\author{
進 健司, ${ }^{a, b}$ 小林大介, ${ }^{*}, a$ 川尻雄大, ${ }^{a}$ 猪狩圭介, ${ }^{c}$ 光安博志, ${ }^{c}$ 村上智哉, ${ }^{c}$ \\ 堤 一樹, ${ }^{c}$ 金澤康範, ${ }^{b}$ 神村英利, ${ }^{d}$ 島添隆雄 ${ }^{a}$
}

\section{Effect of Digital Labels on Electronic Medical Records for Reducing the Use of Benzodiazepine Receptor Agonists}

\begin{abstract}
Kenji Shin,${ }^{a, b}$ Daisuke Kobayashi, ${ }^{*, a}$ Takehiro Kawashiri, ${ }^{a}$ Keisuke Ikari, ${ }^{c}$ Hiroshi Mitsuyasu, ${ }^{c}$ Tomoya Murakami, ${ }^{c}$ Kazuki Tsutsumi, ${ }^{c}$ Yasunori Kanazawa, ${ }^{b}$ Hidetoshi Kamimura, ${ }^{d}$ and Takao Shimazoe ${ }^{a}$ ${ }^{a}$ Department of Clinical Pharmacy and Pharmaceutical Care, Graduate School of Pharmaceutical Sciences, Kyushu University; 3-1-1 Maidashi, Higashi-ku, Fukuoka 812-8582, Japan: bepartment of Pharmacy, Iizuka Hospital; 3-83 Yoshio-machi, Iizuka, Fukuoka 820-8505, Japan: 'Department of Liaison Psychiatry, Iizuka Hospital; 3-83 Yoshio-machi, Iizuka, Fukuoka 820-8505, Japan: and ${ }^{d}$ Department of Pharmacy, Fukuoka University Hospital;
\end{abstract} 7-45-1 Nanakuma, Jonan-ku, Fukuoka 814-0180, Japan.

(Received April 2, 2019; Accepted July 12, 2019)

\begin{abstract}
Benzodiazepine receptor agonists (BZDs) should be appropriately used owing to the associated risks of delirium and falls. Since January 2018, the liaison team pharmacist at Iizuka Hospital has been applying digital labels with recommendations for the reduction of use and changes in the medication orders and prescriptions of BZDs on electronic medical records of patients in the surgical ward. This study aimed to verify the effectiveness of reducing the use of BZDs via the implementation of digital labels. Patients in the surgical ward were retrospectively assessed for changes in medication orders and prescription ratios of BZDs before and after the implementation of digital labels. The ratio of the number of digital labels implemented to the number of confirmations of medication orders and prescriptions of BZDs was $15.0 \%$ at the start of implementation; however, the ratio gradually and significantly decreased to $3.6 \%$. The medication order ratio of BZDs was $52.2 \%$ before the implementation of digital labels; however, this ratio decreased to $2.7 \%$ and 5.6\% immediately and 4 months after the implementation of digital labels, respectively. The present study showed that medication orders for BZDs were reduced after the implementation of digital labels and that the reduction effect was maintained for a certain period of time. Thus, the liaison team pharmacist-led approach can contribute to the proper use of BZDs.
\end{abstract}

Key words — liaison team pharmacist; benzodiazepine receptor agonist; digital label; reducing drug; proper use

\section{緒 \\ 言}

ベンゾジアゼピン受容体作動薬 [以下, benzodiazepine (BZD) 系薬] は, 抗不安作用, 筋弛緩 作用, 抗うつ作用, 催眠鎮静作用等の様々な薬理作 用を有している。 また，バルビッレート系薬剂に比 へ，耐性と依存性の形成リスクが低いことや大量服 薬時の致死性が低いことから臨床現場で汎用されて いる。 その一方で，せん妄, ${ }^{1-3)}$ 転倒・骨折, ${ }^{4-6)}$ 認 知機能低下7)や臨床用量における依存形成8,9)などの

$a$ 九州大学大学院薬学研究院臨床育薬学分野, $b$ 飯塚病 院薬剂部, c飯塚病院リエゾン精神科, $d$ 福岡大学病院 薬剂部

*e-mail: dkobayas@med.kyushu-u.ac.jp
問題が指摘されている. 日本老年医学会における高 齢者の安全な薬物療法ガイドライン 2015 では, BZD 系薬は高齢者で重篤な有害事象が出易く, よ り安全な代替薬があると判断される薬剤に位置づけ られており，使用を控えることが推奨されてい る. ${ }^{10)} \mathrm{BZD}$ 系薬は治療用量でも長期投与を避ける ことが望ましく, 11,12) 頓服で使用する場合において

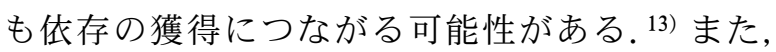
BZD 系薬の適正使用を推進する観点から，2017 年 3 月に医薬品医療機器総合機構による BZD 系薬の 依存性に関する注意喚起がなされ, ${ }^{14)} 2018$ 年度の診 療報酬改定では向精神薬調整連携加算が新設され た。これらのことから，BZD 系薬に対する適正使 用の取り組みを進めていくことは，ますます重要と 
なっている.

このような状況下，飯塚病院リエゾンチームでは 変更可能と考えられる BZD 系薬が指示・処方され ることを防止するため，外科系病棟入院患者の不眠 に対して本剤が指示・処方された場合に，薬剤師が BZD 系薬の減薬や変更の推奨を記した内容をス夕 ンプ形式にして電子診療録に貼付する取り組みを開 始した.

これまでに，入院患者に対する BZD 系薬の減薬 への取り組みとして Beers Criteria に基づく薬物療 法の実施, ${ }^{15)}$ タンドスピロンの使用, ${ }^{16)}$ 医療スタッ フへの転倒・転落と睡眠薬に関する情報提供や病棟 定数薬の見直し17)等による成果が報告されている.

しかし，リエゾンチームが入院患者に対する BZD 系薬の減薬に取り組んだ報告は少なく, ${ }^{18)}$ これを薬 剂師主導で実施した報告はない。

そこで今回，リエゾンチーム薬剤師による BZD 系薬減薬に対するスタンプ貼付の効果について検証 することを目的として，外科系病棟におけるスタン プ貼付後の BZD 系薬変更状況を解析し，スタンプ 貼付前後の BZD 系薬の指示・処方割合とせん妄・ 転倒の発現割合を評価した。

\section{方法}

1. スタンプの貼付 リエゾンチームの医師と 薬剤師が協議して，スタンプ貼付の対象となる

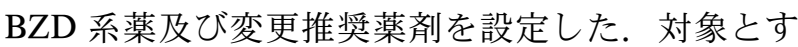
る BZD 系薬は，入院中に不眠に対して新規に処方 又は不眠時薬で指示される経口薬とした，検査前投 与薬やアルコール離脱の予防・治療目的で新規に処 方される BZD 系薬は，スタンプ貼付の対象から除 外した．变更推奨薬剤を Table 1 に示す．第一推奨 薬剂は，不眠症に適応があり単回投与で効果が期待 できることからスボレキサントとし，第二推奨薬剤 は，単回投与で効果が期待できるトラゾドンとし た。 ラメルテオンは有効性の評価に時間を要するこ とから定時処方薬での第三推奨薬剤とした. ${ }^{19-21)}$ 推 奨薬剤はアレルギー・副作用歴，重複投与，相互作 用，禁忌の患者情報を確認した上で選択した。これ らの薬剤を推奨できない場合は，リエゾンチーム医 師と協議してその他の薬剤を推奨することとした.

日本老年医学会における高齢者の安全な薬物療法 ガイドライン 2015 の対象年齢10)を参考とし，70 歳
Table 1. Recommended Drugs for Prescription Change

Recommended drugs

Drugs to be taken every day

(1) Suvorexant $15 \mathrm{mg}$

(2) Trazodone hydrochloride $25 \mathrm{mg}$

(3) Ramelteon $8 \mathrm{mg}$

(4) Drugs determined based on a discussion with a physician and a pharmacist on the liaison team

Drugs for insomnia

(1) Suvorexant $15 \mathrm{mg}$ (up to once per day)

(2) Trazodone hydrochloride $25 \mathrm{mg}$ (up to two times per day, after an hour or more)

(3) Drugs determined based on a discussion with a physician and a pharmacist on the liaison team

以上の外科系病棟の入院患者に対象薬剤が処方され た場合，薬剤師がスタンプを診療録に貼付した。貼 付したスタンプの例を Fig. 1 に示す。スタンプに は，BZD 系薬のリスクと使用を避けることについ て示し，指示あるいは処方されている BZD 系薬の 薬剂名, 変更推奨薬剤名とその用法・用量を記載し た。また，処方医師が BZD 系薬の減薬や変更に迷 う際の相談応需ができるようにリエゾンチーム薬剤 師の PHS 番号も記載した。 BZD 系薬の指示・処方 確認日は，入院から 3 日目，7 日目，以後 1 週間毎 とし，確認日が休日の場合は翌営業日に確認するこ ととした．スタンプ貼付後も BZD 系薬が変更され ずに指示・処方が継続されている場合，2回目以降 の確認時にはスタンプは貼付しないこととした。た だし，スタンプ貼付時の対象であった BZD 系薬と は異なる BZD 系薬が指示された場合や定時薬で新 規に処方された場合は再度スタンプを貼付した。

2. スタンプ貼付後の BZD 系薬変更状況 ス タンプ貼付期間は 2018 年 1 月 22 日-5 月 31 日と し，本取り組みの運用が軌道に乗った 2018 年 3 月 からの BZD 系薬指示・処方確認件数, スタンプ貼 付件数, スタンプ貼付後の BZD 系薬変更件数, 変 更推奨薬剤受諾件数, 推奨薬剤の効果を調査した. 推奨薬剤の効果は診療録より推奨薬剤使用後の不眠 に対する効果の記載内容を基に評価した．また，推 奨薬剤から BZD 系薬に再変更された件数を調査し た.

3. スタンプ貼付前後の BZD 系薬の指示・処方 割合とせん妄·転倒の発現割合の比較 外科系病 棟入院患者において，スタンプ貼付前の 2017 年 12 


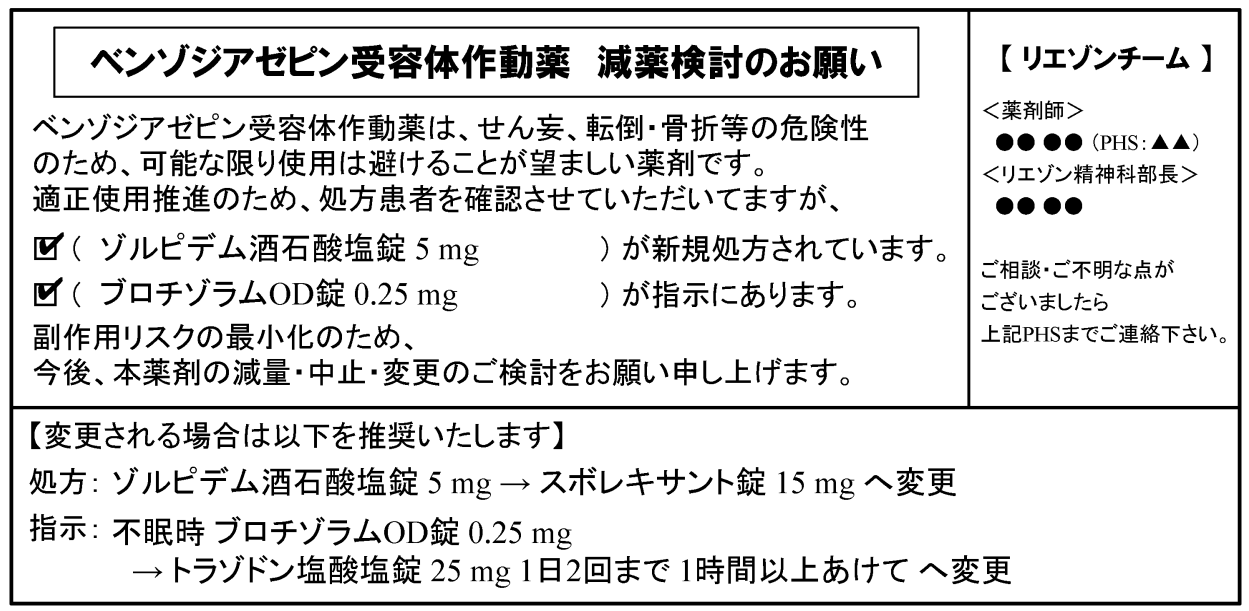

Fig. 1. Example of a Digital Label for Reducing the Use of Benzodiazepine Receptor Agonists

月，貼付期間終了直後の 2018 年 6 月，貼付期間終 了から 4 力月後の 2018 年 10 月の各 1 力月間におけ る BZD 系薬の指示・処方割合とせん妄・転倒の発 現割合を比較した．BZD 系薬の指示・処方割合の 調査では，スタンプ貼付期間の処方確認方法と同様 に入院から 3 日目，7 日目，以後 1 週間毎の 70 歳 以上の患者を対象とした。 BZD 系薬の指示・処方 割合の算出方法は, 指示・処方内容を確認した患者 に対する BZD 系薬が入院中に不眠に対して新規に 指示・処方された患者の割合とし, 同一患者が複数 回確認される場合は初回確認時のみを対象として算 出した。 せん妄・転倒発現割合の調査では, 入院日 数に関係なく70 歳以上の患者を対象として割合を 算出した. なお，せん妄発現時にはリエゾン精神科 ヘコンサルトされるケースと主治医が対応するケー スがあると考えられるが，後者は集計が困難である ことから, せん妄の発現とは, リエゾン精神科へコ ンサルトがあった患者のうちリエゾン精神科医師が せん妄と診断したケースとした。 また, 飯塚病院で は看護師は患者転倒発現時に独自の転倒入力システ ムを用いて報告することとされており，転倒の発現 とは，その報告があるケースとした。

4. 統計解析 スタンプ貼付前後の患者背景に ついて性別・診療科はカイ二乗検定，年齢は Kruskal-Wallis 検定を用いて解析した。また，ス夕 ンプ貼付期間の貼付割合の変化, スタンプ貼付前後 の BZD 系薬の指示・処方割合, せん妄発現割合, 転倒発現割合についてカイ二乗検定又はフィッ シャーの正確確率検定を用いて解析した。 解析ソフ
トは JMP Pro 13 (SAS Institute Inc., Cary) を使用 し，いずれも危険率が $5 \%$ 未満の場合を統計学的有 意と判定した.

\section{5. 倫理的配慮本研究は「ヘルシンキ宣言」} 及び「人を対象とする医学系研究に関する倫理指針」 を遵守し, 飯塚病院倫理委員会 (承認番号 R-18148) 及び九州大学医系地区部局臨床研究倫理審査委員会 （承認番号 30-546）の承認を得て実施した.

\section{結果}

1. 患者背景 患者背景を Table 2 に示す。 ス タンプ貼付前は男性 53 名, 女性 39 名, 貼付期間終 了直後は男性 43 名, 女性 31 名, 貼付期間終了から 4 力月後は男性 55 名, 女性 40 名であった. 年齢の 中央值はそれぞれ 78.5 歳, 77 歳, 78 歳であり, 診 療科はいずれも外科が最も多かった。 スタンプ貼付 前, 終了直後, 4 力月後の患者について, 性別・年 齢・診療科のいずれも違いはみられなかつた.

2. スタンプ貼付件数及び BZD 系薬変更状況 スタンプ貼付実施状況を Table 3 に示す。 BZD 系薬の指示・処方確認件数は 154.7 件/月, スタン プ貼付件数は 12.3 件/月であった. スタンプ貼付に よる推奨薬剂提案件数の内訳は，スボレキサントが 30 件, トラゾドンが 7 件であった。第二推奨薬剤 のトラゾドンを提案した背景は，「スボレキサント が使用されており，スボレキサントの提案では過量 投与となるため」が 6 件, 「ベラパミルが使用され ており，スボレキサントの提案では相互作用がある ため」が 1 件であった。 BZD 系薬指示・処方確認 
Table 2. Patients Characteristics

\begin{tabular}{|c|c|c|c|c|}
\hline Characteristics & $\begin{array}{l}\text { Before implementa- } \\
\text { tion of digital labels } \\
\qquad(n=92)\end{array}$ & $\begin{array}{l}\text { Immediately after } \\
\text { implementation of } \\
\text { digital labels } \\
(n=74)\end{array}$ & $\begin{array}{l}\text { Four months after } \\
\text { implementation of } \\
\text { digital labels } \\
(n=95)\end{array}$ & $p$ value \\
\hline \multicolumn{5}{|l|}{$\operatorname{Sex}(n)$} \\
\hline Male & 53 & 43 & 55 & \multirow{2}{*}{$0.998^{\mathrm{a}}$} \\
\hline Female & 39 & 31 & 40 & \\
\hline \multicolumn{5}{|l|}{ Age $(n)$} \\
\hline Median (min-max) & $78.5(70-91)$ & $77(70-91)$ & $78(70-91)$ & $0.426^{\mathrm{b}}$ \\
\hline \multicolumn{5}{|l|}{ Clinical departments $(n)$} \\
\hline Surgery & 40 & 33 & 39 & \multirow{18}{*}{$0.232^{\mathrm{a}}$} \\
\hline Except for Surgery & 52 & 41 & 56 & \\
\hline General practice & 16 & 6 & 6 & \\
\hline Thoracic surgery & 10 & 5 & 7 & \\
\hline Ophthalmology & 8 & 7 & 16 & \\
\hline Otorhinolaryngology-head and neck surgery & 4 & 6 & 4 & \\
\hline Respiratory medicine & 4 & 4 & 2 & \\
\hline Department of palliative medicine & 3 & 2 & 1 & \\
\hline Gastroenterology & 2 & 4 & 5 & \\
\hline Orthopedic surgery & 2 & 1 & 3 & \\
\hline Neurology & 1 & 2 & 6 & \\
\hline Hematology & 1 & 1 & 2 & \\
\hline Cardiology & 1 & 0 & 0 & \\
\hline Internal medicine & 0 & 1 & 1 & \\
\hline Cardiovascular surgery & 0 & 1 & 0 & \\
\hline Nephrology and diabetes & 0 & 1 & 0 & \\
\hline Neurosurgery & 0 & 0 & 2 & \\
\hline Department of internal medicine/rheumatology & 0 & 0 & 1 & \\
\hline
\end{tabular}

${ }^{\mathrm{a}}$ Chi-squared test, ${ }^{\mathrm{b}}$ Kruskal Wallis test.

Table 3. Situation of Medication Orders and Prescriptions of Benzodiazepine Receptor Agonists after the Implementation of Digital Label

\begin{tabular}{lrrrr}
\hline \hline \multicolumn{1}{c}{ Item } & March & April & May & Average \\
\hline Confirmation of medication orders and prescriptions of benzodiazepine & 140 & 155 & 169 & 154.7 \\
receptor agonists & $21(15.0)$ & $10\left(6.5^{*}\right)$ & $6\left(3.6^{*}\right)$ & $12.3(8.0)$ \\
Implementation of digital labels (\%) & $10(47.6)$ & $5(50.0)$ & $4(66.7)$ & $6.3(51.4)$ \\
Changes of benzodiazepine receptor agonists $(\%)^{a}$ & $9(90.0)$ & $5(100.0)$ & $3(75.0)$ & $5.7(89.5)$ \\
Acceptance of recommended drugs $(\%)^{b}$ & & & & \\
\hline
\end{tabular}

${ }^{a}$ Ratio of the number of changes of benzodiazepine receptor agonists to the number of digital labels implemented. ${ }^{\mathrm{b}}$ Ratio of acceptance of recommended drugs from benzodiazepine receptor agonists. ${ }^{*} p<0.05$; Fisher's exact test (vs. March).

件数に対するスタンプ貼付件数の割合は，調查開始 時の 3 月は $15.0 \%$ であっが，徐々に減少し，5月 には $3.6 \%$ と有意に減少した $(p<0.001)$ ，BZD 系 薬変更率は $51.4 \%$, 変更推奨薬剤受諾率は $89.5 \%$ であった．スタンプ貼付件数のうち，定時処方薬に 対する貼付は 1 件のみで，それ以外は不眠時指示薬 に対するものであった。推奨薬剤が受諾された 17 件のうち患者に使用されたケースは 6 件であり，推
奨薬剂の使用効果が有効だつたのは 4 件，不明が 2 件であった。 また，推奨薬剤から BZD 系薬に再変 更されたケースはなかつた．処方医師の相談応需件 数は 2 件であった。腎機能障害患者における不眠時 スボレキサントの使用の是非，高齢患者における不 眠時スボレキサントの用量に関する相談であり，い ずれも推奨用量で使用可能であると回答するととも に，生理機能低下による傾眠・頭痛等の副作用発現 


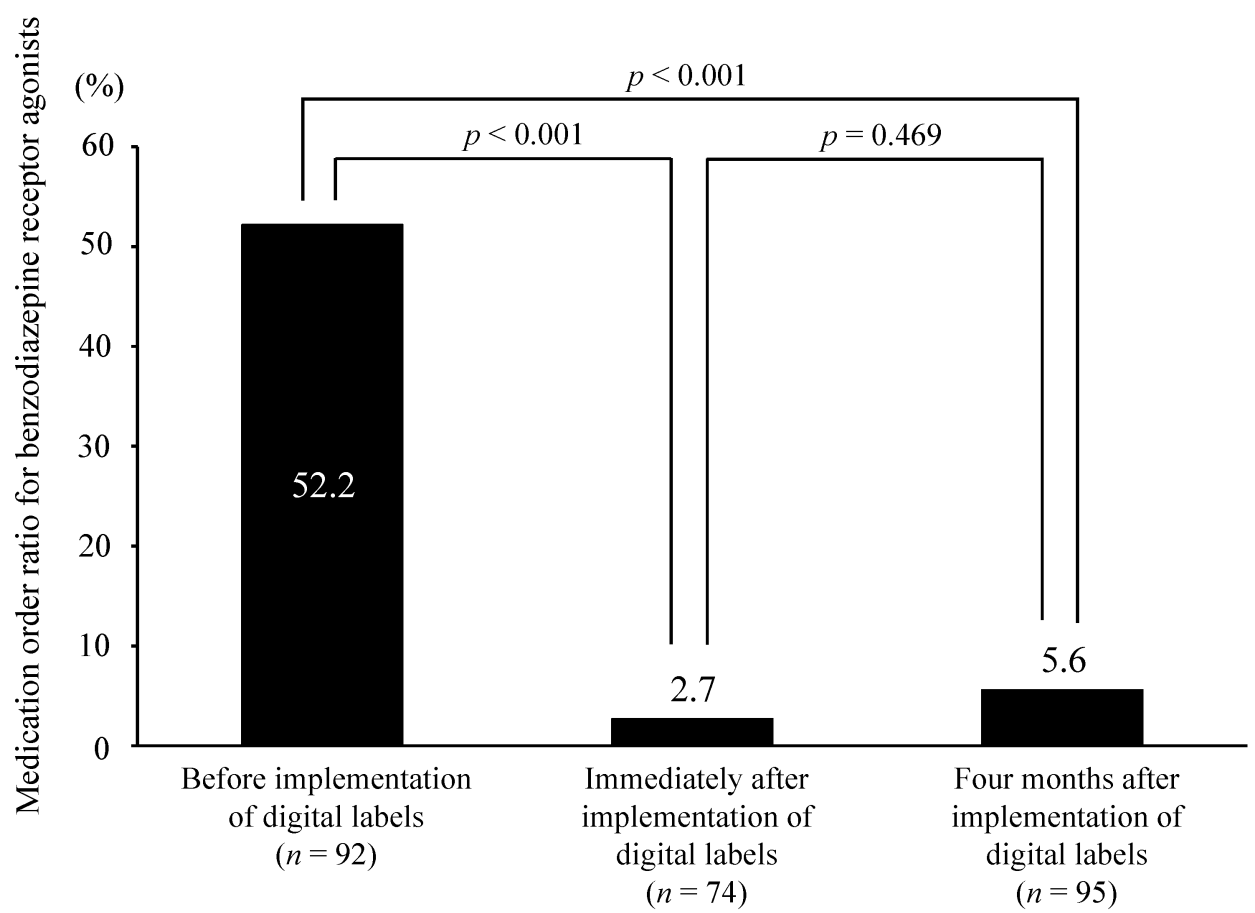

Fig. 2. Medication Order Ratios of Benzodiazepine Receptor Agonists before and after the Implementation of Digital Labels

には注意が必要であることを情報提供した。

\section{3. スタンプ貼付前後の BZD 系薬の指示・処方} 及びせん妄・転倒発現状況スタンプ貼付前, 終 了直後， 4 力月後のいずれも不眠に対して新規に処 方された経口 BZD 系薬はなく，すべて不眠時指示 薬であった。 BZD 系薬の指示状況を Fig. 2 に示 す．スタンプ貼付前の BZD 系薬の指示率は $52.2 \%$ であり, 貼付期間終了直後は $2.7 \%, 4$ 力月後は $5.6 \%$ であった。 スタンプ貼付前と比べて終了直後・4 カ 月後はともに有意に低下し（いずれも $p<0.001 ）$, 終了直後と 4 力月後については有意な差はみられな かった $(p=0.469)$.

せん妄発現状況を Fig. 3 に示す. スタンプ貼付 前のせん妄発現率は $3.3 \%$, 貼付期間終了直後, 4 力月後はともに $0 \%$ であり, 4 力月後の発現率に ついては低下傾向を示した $(p=0.055)$. なお，又 タンプ貼付前のせん妄発現患者における BZD 系薬 服用率は 75.0\%（3 名）であった。

転倒発現状況では，スタンプ貼付前の転倒発現率 は $0.8 \%$ であり，貼付期間終了直後は $0.9 \%, 4$ 力月 後は $1.6 \%$ であた. スタンプ貼付前と比べて終了 直後, 4 力月後ともに有意な差はみられなかつた.

入院前から継続されている薬剤も含めた BZD 系 薬の処方割合は，スタンプ貼付前が $27.0 \%$, 貼付
期間終了直後が $21.3 \%, 4$ カ月後が $10.9 \%$ であり, スタンプ貼付前と比べて 4 カ月後は有意に低かった $(p=0.001)$.

\section{考察}

本研究において，リエゾンチーム薬剂師が診療録 にスタンプを貼付することにより BZD 系薬の指 示・処方を回避できることが明らかとなった.

せん妄や転倒は患者の入院期間を延長させ, ${ }^{22,23)}$ 医療費の上昇に影響を及ぼすことが報告されてい る. ${ }^{24,25)}$ せん妄や転倒に対する予防的対策を進める ことは患者の苦痛緩和に加えて医療経済の観点から も非常に重要である。せん妄・転倒の要因には BZD 系薬の使用が挙げられ, ${ }^{26,27)}$ 特に高齢者におい て BZD 系薬が使用されることを回避するための予 防的介入として，リエゾンチーム内で協議しスタン プ形式での貼付の取り組みを開始した。本研究にお いて，スタンプ貼付件数はスタンプ貼付後, 徐々に 低下した。 スタンプには BZD 系薬のせん妄や転倒 リスクについて記しており，医師は貼付されたス夕 ンプの記載内容を目にすることでその認識が次第に 高まり BZD 系薬の減薬につながつたものと推察さ れる. スタンプ貼付後の BZD 系薬変更率は 5 割程 度であったが，スタンプ貼付期間終了後の BZD 系 


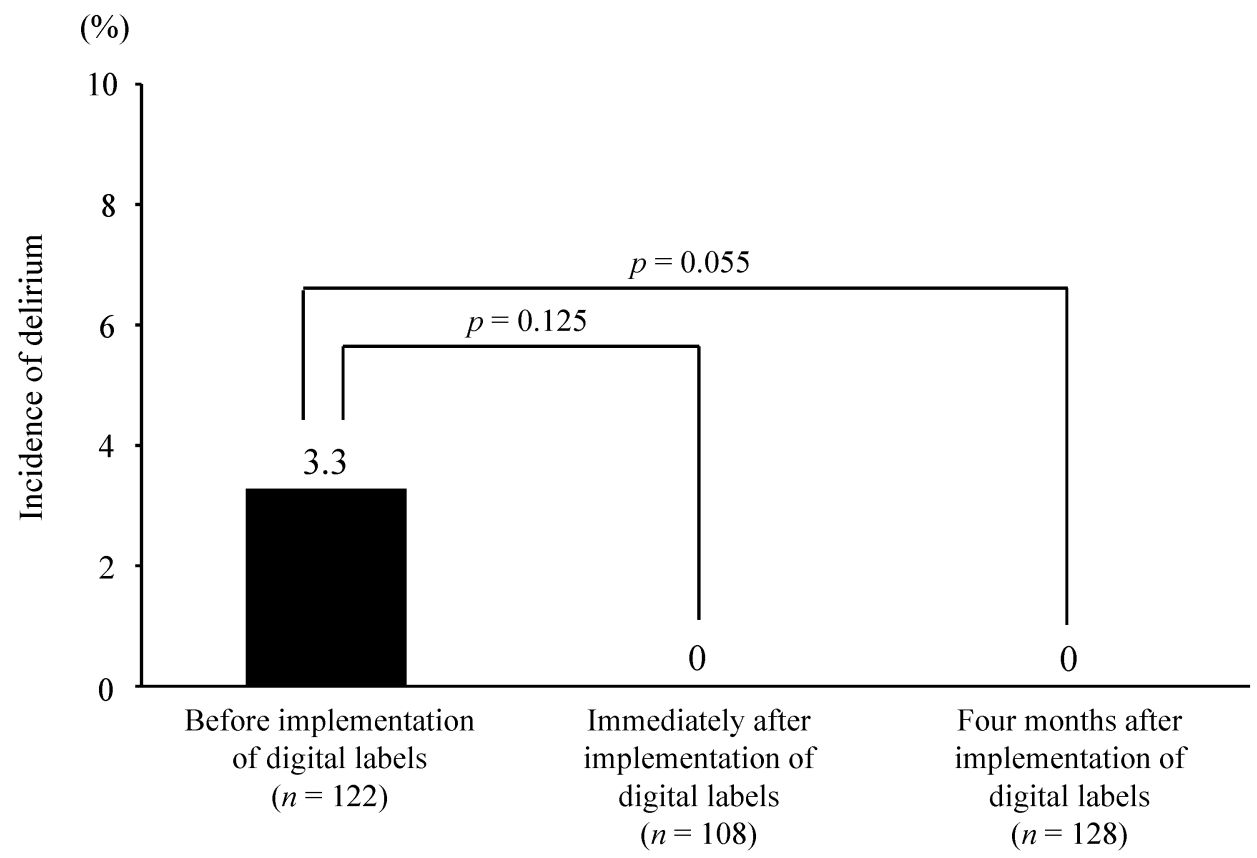

Fig. 3. Incidence of Delirium before and after the Implementation of Digital Labels

薬の指示率は低值を示した。これは，スタンプが貼 付された患者の BZD 系薬は変更されなくとも，新 規入院患者に医師が指示・処方する際には BZD 系 薬を避けた薬剤選択を行ったことが推察される。ま た，スタンプ貼付によるリエゾンチーム推奨薬剤の 受諾率は 9 割に近い高い值であった。推奨薬剤の使 用効果については，症例数は少ないものの過半数で 有効性が得られており，推奨薬剤から BZD 系薬に 再び変更されるケースもなかった。ささに，相談応 需体制を設けて対応したケースもあった。これらの ことから，リエゾンチームによる BZD 系薬の変更 薬剂に対する支援は，主治医の治療負担や不安を増 すことなくせん妄や転倒のリスク回避につながる適 切な支援ができたと考えられる。

BZD 系薬の指示率は，スタンプ貼付前に比べて スタンプ貼付期間終了直後は有意に低下し，4 カ月 後も有意に低下していたことから，本取り組みは BZD 系薬の指示回避に効果的であるとともに，そ の効果は一定期間維持されることが示唆された。せ ん妄発現率も 4 カ月後は低下傾向を示したが，ス夕 ンプ貼付前のせん妄発現患者のうち過半数は BZD 系薬を服用していたことから，本取り組みによる BZD 系薬の指示率低下がせん妄発現率の低下につ ながったと考えられた．しかしながら，本調査での せん妄発現基準には主治医がせん妄に対応したケー
スは含まれていないことから，せん妄発現率の結果 に偏りが生じている可能性も考えられる．また，本 研究の調査対象は外科系病棟のみで患者数が限られ ていたこと，スタンプ貼付前の発現率が低值であつ たこと，せん妄や転倒の発現には BZD 系薬以外に も多くの要因が存在することから, ${ }^{28-30)}$ 一病棟での 本取り組みによる BZD 系薬の回避のみではせん妄 や転倒発現率の低下は示されなかったものと思われ る.しかし，本研究においてスタンプ貼付後にせん 妄は発現しておらず，外科系病棟以外でもスタンプ 貼付を行い，その効果を検証してくことが必要だと 考えられる。

設定した BZD 系薬の変更推奨薬剤について，わ れわれは，第二推奨薬剤にトラゾドンを挙げてい る.トラゾドンは睡眠薬の適正使用・休薬ガイドラ インでの不眠症の薬物療法において，せん妄や転倒 リスクが報告されている BZD 系薬の使用を避ける 場合に選択肢に挙がること, ${ }^{31)}$ 高齢者やせん妄リス ク患者の不眠に使用されていること, ${ }^{21,26)}$ 原発性不 眠症患者に対する効果が報告されていること等が あり，臨床において不眠に使用されるケースもある と思われる，しかし，トラゾドンの適応は「うつ 病・うつ状態」であることから本取り組みにおいて 適応外使用の問題について検討する必要がある。卜 ラゾドンを使用する際は，使用目的，予想される効 
果及び副作用，副作用が生じた場合の対応，他の治 療薬を使用した場合の利点と欠点等を患者に十分に 説明して使用の同意を得るとともに，トラゾドンが 適応外使用であることと患者説明の重要性について 処方医師にも情報提供する必要があると考えられる.

本研究の限界としては，スタンプ貼付の取り組み 後, 4 力月を超える長期にわたる有用性の評価がで きていないことが挙げられる，BZD 系薬の危険性 に関する医師の認識は次第に薄れていく可能性や, 新しい医師が配属されることで BZD 系薬の指示・ 処方割合が再び高まることも考えられる。したがつ て，定期的にスタンプ貼付を実施することが必要だ と考えられる。

本研究により, リエゾンチーム薬剤師がスタンプ 形式を用いた取り組みを行うことで BZD 系薬の指 示・処方の回避に貢献できることが示唆された。な んらかの事情で推奨薬剤を提案できない場合には, リエゾン医師と協議することとしていたが，調査期 間中に，そのようなケースはなかった。しかし， BZD 系薬の変更を一律に推奨するのではなく，ア レルギー・・副作用歴，重複投与等の患者情報を確認 して妥当性を検討した上で推奨することからも薬剤 師による介入の意義があると考えられる，BZD 系 薬の指示・処方状況を確認し外科系病棟における再 導入の必要性を検討すること，また，取り組み病棟 の拡大を図ることが BZD 系薬の指示・処方の更な る回避につながるものと考えられ，今後もリエゾン チームで協働し，BZD 系薬の適正使用を進めてい きたい.

\section{謝辞本研究は飯塚病院臨床研究助成金制度の} 支援を受けて実施したものである.

利益相反＼cjkstart開示すべき利益相反はない.

\section{REFERENCES}

1) Mizukami K., Japanese Journal of Psychiatric Treatment, 28, 1005-1009 (2013).

2) Gaudreau J. D., Gagnon P., Roy M. A., Harel F., Tremblay A., Psychosomatics, 46, 302-316 (2005).

3) Marcantonio E. R., Juarez G., Goldman L., Mangione C. M., Ludwig L. E., Lind L., Katz
N., Cook E. F., Orav E. J., Lee T. H., $J A M A, 272,1518-1522$ (1994) .

4) Shigeyama M., Taguchi M., Maeyama N., Yuhara H., Asado S., Nagata S., Kati T., Fujita K., Jpn. J. Pharm. Health Care Sci., 37, 49-55 (2011).

5) Wagner A. K., Zhang F., Soumerai S. B., Walker A. M., Gurwitz J. H., Glynn R. J., Ross-Degnan D., Arch. Intern. Med., 164, 1567-1572 (2004) .

6) Sorock G. S., Shimkin E. E., Arch. Intern. Med., 148, 2441-2444 (1988).

7) Hindmarch I., Arch. Intern. Med., 63, 10851094 (2009).

8) Toda K., Jpn. J. Clin. Psychopharmacol., 16, 867-878 (2013) .

9) Uchimura N., Jpn. J. Clin. Psychopharmacol., 9, 2003-2010 (2006) .

10) The Japan Geriatrics Society, "Guidelines for Medical Treatment and Its Safety in the Elderly 2015," Medical View Co., Ltd., Tokyo, 2016, pp. 22-31.

11） Tomita M., Jpn. J. Clin. Med., 68, 1516-1520 (2010) .

12) Griffiths R. R., Weerts E. M., Psychopharmacology, 134, 1-37 (1997).

13) Westra H. A., Stewart S. H., Curr. Pharm. Des., 8, 59-74 (2002).

14) Pharmaceuticals and Medical Devices Agency, Dependence associated with benzodiazepine receptor agonists: 〈http://www.pmda.go.jp/ files/000217046.pdf $\rangle$, cited 19 November, 2018.

15) Kashyap M., D’Cruz S., Sachdev A., Tiwari P., Int. J. Risk Saf. Med., 27, 209-217 (2015) .

16) Iga R., Degawa E., Fukushima T., Watanabe K., Kasahara M., Ohira Y., Hayashi H., Tatsumi S., Miura M., J. Jpn. Soc. Hosp. Pharm., 50, 1235-1239 (2014).

17) Sakata H., Maeda T., J. Jpn. Soc. Hosp. Pharm., 41, 1261-1265 (2005).

18) Takahashi Y., The Pharmaceuticals Monthly, 58, 1927-1930 (2016).

19) Hatta K., Kishi Y., Wada K., Takeuchi T., Odawara T., Usui C., Nakamura H., DELIRIA-J Group, JAMA Psychiatry, 71, 397-403 (2014).

20) Hatta K., Kishi Y., Wada K., Takeuchi T., Ito 
S., Kurata A., Murakami K., Sugita M., Usui C., Nakamura H., DELIRIA-J Group, J. Clin. Psychiatry, 78, e970-e979 (2017).

21) Inoue S., The Pharmaceuticals Monthly, 60, 1648-1653 (2018).

22) Saravay S. M., Lavin M., Psychosomatics, 35, 233-252 (1994).

23) Miyakoshi K., Takahashi S., Muranaga S., Suzuki M., Natsume T., M. B. Med. Reha., 221, 1-7 (2018) .

24) Franco K., Litaker D., Locala J., Bronson D., Psychosomatics, 42, 68-73 (2001).

25) Hayashi Y., THE BONE, 23, 181-184 (2009).

26) Kikkawa A., Wada K., The Pharmaceuticals Monthly, 58, 3439-3444 (2016).

27) Landi F., Onder G., Cesari M., Barillaro C.,
Russo A., Bernabei R., Silver Nerwork Home Care Study Group, J. Gerontol. A Biol. Sci. Med. Sci., 60, 622-626 (2005).

28) Lipowski Z. J., JAMA, 258, 1789-1792 (1987).

29) Rao S. S., Am. Fam. Physician., 72, 81-88 (2005).

30) Woolf A. D., Akesson K., BMJ, 327, 89-95 (2003).

31) Japanese Society of Sleep Research, "Clinical Practice Guideline for Appropriate Use and Cessation of Drug on Hypnotics."': 〈http:// www.jssr.jp/data/pdf/suiminyaku-guideline. pdf $\rangle$, cited 14 May, 2019.

32) Roth A. J., McCall W. V., Liguori A., $J$. Sleep Res., 20, 552-558 (2011). 